\title{
EVALUATION OF THE POSSIBLE PROTECTIVE EFFECT OF METFORMIN IN CISPLATIN - INDUCED NEPHROTOXICITY IN ADULT MALE ALBINO RATS
}

\author{
By
Mohammed Assasa*, Sayed Abd El-Raheem**, Abd El-Lateef Said***, and Ashraf I. Hassan* \\ Departments of Forensic Medicine*, Pathology** and Pharmacology***, Faculty of \\ Medicine, Al Azhar University, Cairo
}

\begin{abstract}
Backgrounds: Clinical use of cisplatin is limited by its nephrotoxicity as cisplatin -induced oxidative stress which leads ultimately to kidney dysfunction.

Objective: Evaluation of the nephron-protective effect of metformin against nephrotoxicity induced by cisplatin in adult albino rats.

Materials and Methods: Sixty adult male albino rats were divided randomly into 6 equal groups: Group I (control group) was injected with $1 \mathrm{ml}$ isotonic saline solution intraperitoneally (I.P). Group 2 was injected with single dose of cisplatin I.P $3.5 \mathrm{mg} / \mathrm{kg}$. Group 3 was injected with single dose of cisplatin I.P $7.5 \mathrm{mg} / \mathrm{kg}$. Group 4 was given an oral dose of metformin $(350 \mathrm{mg} / \mathrm{kg} /$ day for 10 days). Group 5 was given $100 \mathrm{mg}$ $\mathrm{kg} /$ day metformin for 3 days before cisplatin injection I.P at a dose of $7.5 \mathrm{mg} / \mathrm{kg}$ on day four, and metformin continued for 7 days after. Group 6 was given $350 \mathrm{mg} \mathrm{kg} / \mathrm{day}$ metformin for 3 days before cisplatin injection I.P at a dose of $7.5 \mathrm{mg} / \mathrm{kg}$ on day four, and metformin continued for 7days after. Body weight of each rat was recorded on day 1, 4, 7 and 10 and average weight for each group was calculated. At the end of specified duration (10 days), rats were sacrificed and both kidneys were excised, processed and stained with Hematoxylin and Eosin for histopathological study and with Periodic Acid-Schiff (PAS) and Mallory's stain stains for histochemical study.

Results: Rats injected with high dose of cisplatin $(7.5 \mathrm{mg} / \mathrm{kg})$ showed more loss of average body weight and higher blood urea nitrogen (BUN) and serum creatinine (Cr) levels than those rats injected with $3.5 \mathrm{mg} / \mathrm{kg}$ cisplatin. Rat group injected with high dose of cisplatin $(7.5 \mathrm{mg} / \mathrm{kg})$ and given low dose metformin $(100$ $\mathrm{mg} / \mathrm{kg} /$ day) showed less loss of average body weight and improved renal functions than rat group given high dose of cisplatin $(7.5 \mathrm{mg} / \mathrm{kg})$ and high dose of metformin $(350 \mathrm{mg} / \mathrm{kg} /$ day $)$. Histopathological examination with $\mathrm{H} \& \mathrm{E}$ and histochemical examination with PAS and Mallory stains revealed mild glomerular, tubular and interstitial changes in cisplatin low dose group compared to cisplatin high dose group which showed more renal damages. Group given metformin low dose + cisplatin high dose showed less renal damage than those given high dose of cisplatin+ high dose metformin .
\end{abstract}

Conclusion: Metformin has protective effects against cisplatin -induced nephrotoxicity in adult male albino rats.

Key words: Cisplatin, nephrotoxity, metformin. 


\section{INTRODUCTION}

Cisplatin is an important chemotherapeutic agent useful in the treatment of several cancers. Several side effects of cisplatin have been reported, mainly nephrotoxicity and myelosuppression which limit its clinical use (Florea and Büsselberg, 2011). Inflammation, oxidative stress injury, and apoptosis probably explain part of Cisplatin nephrotoxicity, primarily in the proximal tubular epithelium (Chirino and Pedraza-Chaverri, 2009). Cisplatin or its metabolites may be absorbed by kidney tubular cells through organic cation transporters located on the baso-lateral side of the tubular cells, which will lead to subsequent tubular cell death including apoptosis and necrosis (Gabbiani et al., 2010). Reactive oxygen species production, depletion of antioxidant systems and stimulation of renal accumulation of lipid peroxidation products are the main mechanisms associated with cisplatin-induced nephrotoxicity (Peres and da Cunha, 2013). Cisplatin-induced nephrotoxicity is associated with structural and functional damage to the mitochondria (Zsuzsanna et al., 2012). Cisplatin also binds to DNA and disrupts DNA function (Dasari and Tchounwou, 2014).

Many researches were targeted to find a substance to ameliorate toxic effects of cisplatin on kidney through antagonizing mechanism of cisplatin action. Rutin which has an anti-oxidant and antiinflammatory effect via decreasing the oxidative stress, and repairing the histopathological changes was tested. It showed minimal histopathological findings in the form of minimal interstitial congestion and minimal tubular injury, while glomeruli and the blood vessels appeared normal (Alhoshani et al., 2017). Garlic extract and metformin (MF), alone or in a combination, tried to ameliorate gentamycin induced tubular toxicity (Rafieian-Kopaei et al., 2013). Ceftriaxone which had anti-fibrotic potential acts as a nephron-protective agent and could be used as adjuvant therapy to improve cisplatin-induced nephrotoxicity, as Ceftriaxone given before cisplatin treatment improved renal function biomarkers and renal histoarchitecture (Abdel-Daim et al., 2017).

Metformin treatment was found to restore significantly diabetic nephropathyinduced oxidative stress mRNA levels in Streptozatocin diabetic nephropathy (Alhaider et al., 2011). Various studies had emphasized the anti-inflammatory and antioxidant role of metformin through multiple mechanisms. So, metformin can be an appropriate treatment option for many diseases, when inflammatory processes and oxidative stress play a role in their pathogenesis (Dehkordi et al., 2019). Metformin was found to protect against tubular injury by restoring the biochemical alterations. Moreover, metformin protected podocytes in diabetic nephropathy in rats (Kim et al., 2012).

( The present study aimed to investigate the proved protectivity of metformin in different doses of cisplatin- induced nephrotoxicity).

\section{MATERIALS AND METHODS}

Animals: This study was done on sixty adult male albino rats of local strain; weighing $200 \pm 20 \mathrm{~g}$ and aging 70 days 


\section{EVALUATION OF THE POSSIBLE PROTECTIVE EFFECT OF METFO... 47}

which were obtained from the breeding colony maintained at the animal house of the Nile Company for pharmaceuticals, Cairo, Egypt. All animals procedures were reviewed and approved by the Animals ethics committee, Al-Azhar University, based on the code of practice for the care and use of Animals for Scientific purposes, National Committee for Research, All animal experiments were carried out according to the guidelines and approval of Institutional Animal Ethics Committee. Rats were housed in the animal facility of Faculty of Medicine, AlAzhar University under the normal conditions, each two rats were housed in a clear stainless steel cages. Each cage sized 20X32X20 cm. Rats were kept under constant and controlled temperature (23 \pm $3^{\circ} \mathrm{C}$ ), humidity (about 60\%), with normal light/ dark cycle and fed on a standard rat diet and water ad libitum. Rats were acclimated and monitored under lab conditions for a week.

\section{Chemicals and stains:}

Cisplatin: was purchased from EMIC pharmaceutical industry (Cairo Egypt) in the form of parenteral vial with a concentration of $50 \mathrm{mg} / \mathrm{ml}$. Dose was calculated according to the body weight of each rat.

\section{Metformin}

hydrochloride

(Glucophage): was purchased from Minipharma Merck Serono Company (500 mg metformin hydrochloride tablet). Dose was calculated according to the body weight of each rat.

Periodic Acid-Schiff (PAS): (Product Code: AR165 Staining Interpretation: PAS-positive structures: Magenta, Nuclei: Blue Background: Pink. Control Tissue: Kidney for basement membrane, Dako
Corporation, Denmark). PAS was used to demonstrate the glomerular basement membrane (BM), tubular BM, brush borders, cell borders.

Mallory's stain kit (Staining Interpretation: Collagen fibrils: Deep Blue, Nuclei: Red, Erythrocytes: Gold yellow, Control Tissue: prostate, Dako corporation, Denmark). Mallory's stain was used to demonstrate the collagen fibres in glomerular and tubular BM, and in the interstitium.

Experiment design: Rats were randomly divided into six equal groups:

Group 1: (Control group) was injected with $1 \mathrm{ml}$ isotonic saline solution intraperitoneally (I.P).

Group 2: was injected with cisplatin I.P single dose $3.5 \mathrm{mg} / \mathrm{kg}$ on 4 th day.

Group 3: was injected with cisplatin I.P single dose $7.5 \mathrm{mg} / \mathrm{kg}$ on 4 th day.

Group 4: was given an oral dose of metformin (350 mg/kg /day) for 10 days.

Group 5: was given an oral dose of metformin $100 \mathrm{mg} \mathrm{kg} /$ day for 10 days starting 3 days before giving cisplatin injection I.P at a dose of $7.5 \mathrm{mg} / \mathrm{kg}$ on 4th day and metformin was given for 7 days after.

Group 6: was given an oral dose of 350 $\mathrm{mg} \mathrm{kg}$ /day metformin for 3 days before cisplatin injection I.P at a dose of 7.5 $\mathrm{mg} / \mathrm{kg}$ on day four, and metformin was given for 7days after.

Body weight of each rat was recorded on day 1, 4, 7 and 10. Average weight for each group was calculated. Blood urea nitrogen (BUN) and creatinine $(\mathrm{Cr})$ levels were measured by a colorimetric method 
using commercial kits on an auto analyzer. On day of sacrificing, serum samples were obtained to measure blood urea nitrogen (BUN) and serum creatinine (Cr) for all the rats (Amini et al., 2012). At the end of specified duration (10 days) rats were sacrificed and both kidneys were excised, washed with saline and fixed in $10 \%$ neutral buffered formalin for 24 hours. They were processed in a sequence of ethanol solutions and finally embedded in paraffin wax blocks. Tissues blocks were sectioned at thickness of 4 ?m, followed by deparaffinization by xylene and stained with Hematoxylin \& Eosin (H\&E), Periodic Acid-Schiff (PAS) and Mallory stains.

\section{Statistical Analysis:}

All the statistical analysis were processed using Statistical Program of Social Sciences (SPSS) for windows (version 17, SPSS Inc., Chicago, IL, USA), Values of the measured parameters were expressed as mean value \pm standard deviation (SD).

\section{RESULTS}

Rat body weight: as seen in table (1) both groups II and III shows that average rat body weight was progressively decreased after giving cisplatin injection. On giving cisplatin/ metformin in group $\mathrm{V}$ and group VI obvious less average body weight decrease was noted.

Table (1): Average Recorded Rat Body Weight of different groups (9)

\begin{tabular}{|c|c|c|c|c|c|c|}
\hline Groups & $\begin{array}{c}\text { Group } \\
\text { I }\end{array}$ & $\begin{array}{c}\text { Group } \\
\text { II }\end{array}$ & $\begin{array}{c}\text { Group } \\
\text { III }\end{array}$ & $\begin{array}{c}\text { Group } \\
\text { IV }\end{array}$ & $\begin{array}{c}\text { Group } \\
\text { V }\end{array}$ & $\begin{array}{c}\text { Group } \\
\text { VI }\end{array}$ \\
\hline Day 1 & 244 & 243.6 & 244.2 & 247 & 240.2 & 246 \\
\hline Day 4 & 251.4 & 239.5 & 235 & 251.4 & 238.2 & 241.2 \\
\hline Day 7 & 256.4 & 230 & 230.5 & 253.2 & 238 & 238.6 \\
\hline Day 10 & 260 & 227.2 & 225 & 255 & 236.6 & 237.5 \\
\hline
\end{tabular}

Biological markers: Blood Urea nitrogen (BUN) and serum creatinine $(\mathrm{Cr})$ levels were markedly increased in both groups II and III as seen in table (2) compared to control group I levels. More increase in BUN and serum $\mathrm{Cr}$ on increasing dose of injected cisplatin as seen in group III than that seen in group II. An obvious decrease in in levels of BUN and serum $\mathrm{Cr}$ in groups V and group VI compared to group II and group III on giving metformin with cisplatin. 
Table (2): Blood Urea nitrogen (BUN) and Creatinine

\begin{tabular}{|c|c|c|}
\hline Groups $\begin{array}{r}\text { Serological } \\
\text { Parameters }\end{array}$ & BUN (mg/dl) & $\begin{array}{c}\text { Serum Creatinine } \\
(\mathbf{m g} / \mathbf{d l})\end{array}$ \\
\hline Group 1 & $22.6 \pm 6.3$ & $0.60 \pm 0.3$ \\
\hline Group II & $56.7 \pm 5.5$ & $1.34 \pm 0.4$ \\
\hline Group III & $66.8 \pm 6.7$ & $2.23 \pm 1.4$ \\
\hline Group IV & $46.4 \pm 2.2$ & $1.15 \pm 0.02$ \\
\hline Group V & $51.2 \pm 3.2$ & $1.26 \pm 0.23$ \\
\hline Group VI & $59.6 \pm 2.6$ & $2.1 \pm 0.3$ \\
\hline
\end{tabular}

Histopathological results:

Light microscopical examination of $\mathrm{H} \& \mathrm{E}$ stained slides of kidneys showed the following:

- Group 1 (Control): normal histological structure of cortex and medulla (Figure 1 $\&$ Table 3).

- Group II: (cisplatin low dose): Mild glomerular deformity and hypercellularity with mild narrowing of Bowman's spaces. Tubular epithelium was markedly oedematous with scattered necroticl apoptotic epithelial cells. The interstitium showed markedly dilated congested blood vessels (Figure 2 \&Table 3 )

- Group III: (cisplatin high dose): Marked cortical necrosis, marked deformity and hypercellularity with obliterated Bowman's spaces were noted in viable glomeruli. Tubular epithelium is markedly edematous with numerous necroticl apoptotic tubular cells with numerous intra-tubular hyaline casts. Interstitium showed markedly dilated

Table (3): Histopathological results

\begin{tabular}{|l|c|c|c|c|c|c|c|}
\hline Parameters & \multicolumn{3}{|c|}{ Glomeruli } & \multicolumn{3}{c|}{ Tubules } & Interstitium \\
\cline { 2 - 8 } Groups & Deformity & Cellularity & $\begin{array}{c}\text { Bowman's } \\
\text { space }\end{array}$ & Edema & Necrosis & Casts & BV \\
\hline Group 1 & 0 & 0 & 0 & 0 & 0 & 0 & 0 \\
\hline Group II & + & ++ & + & +++ & + & 0 & +++ \\
\hline Group III & +++ & +++ & +++ & +++ & +++ & +++ & +++ \\
\hline Group IV & 0 & + & 0 & 0 & 0 & 0 & 0 \\
\hline Group V & + & + & 0 & + & + & + & 0 \\
\hline Group VI & +++ & ++ & + & + & + & + & 0 \\
\hline
\end{tabular}

$0=$ No,$+=$ Mild,$++=$ Moderate,$+++=$ Marked

congested blood vessels (Figures 3, 4 \& Table 3)

- Group IV: (metformin high dose): Mild glomerular cellularity with patent Bowman's space and normal histological architecture of tubules were noted (Figure 6 \& Table 3)

- Group V: (cisplatin+ metformin low dose): as seen in (Figure 5 \& Table 3) mild glomerular deformity and cellularity with patent Bowman's spaces, less oedematous proximal tubular epithelium with scattered necroticl apoptotic epithelial cells in contrary to distal tubular epithelium which were markedly edematous with few intra-tubular hyaline casts

- Group VI: (cisplatin+ metformin high dose): Marked glomerular deformity and moderate hypercellularity with narrow to patent Bowman's spaces are seen. Tubular epithelium is mildly oedematous with scattered necroticl apoptotic epithelial cells and few intra-tubular hyaline casts (Figure 6 \& Table 3). 


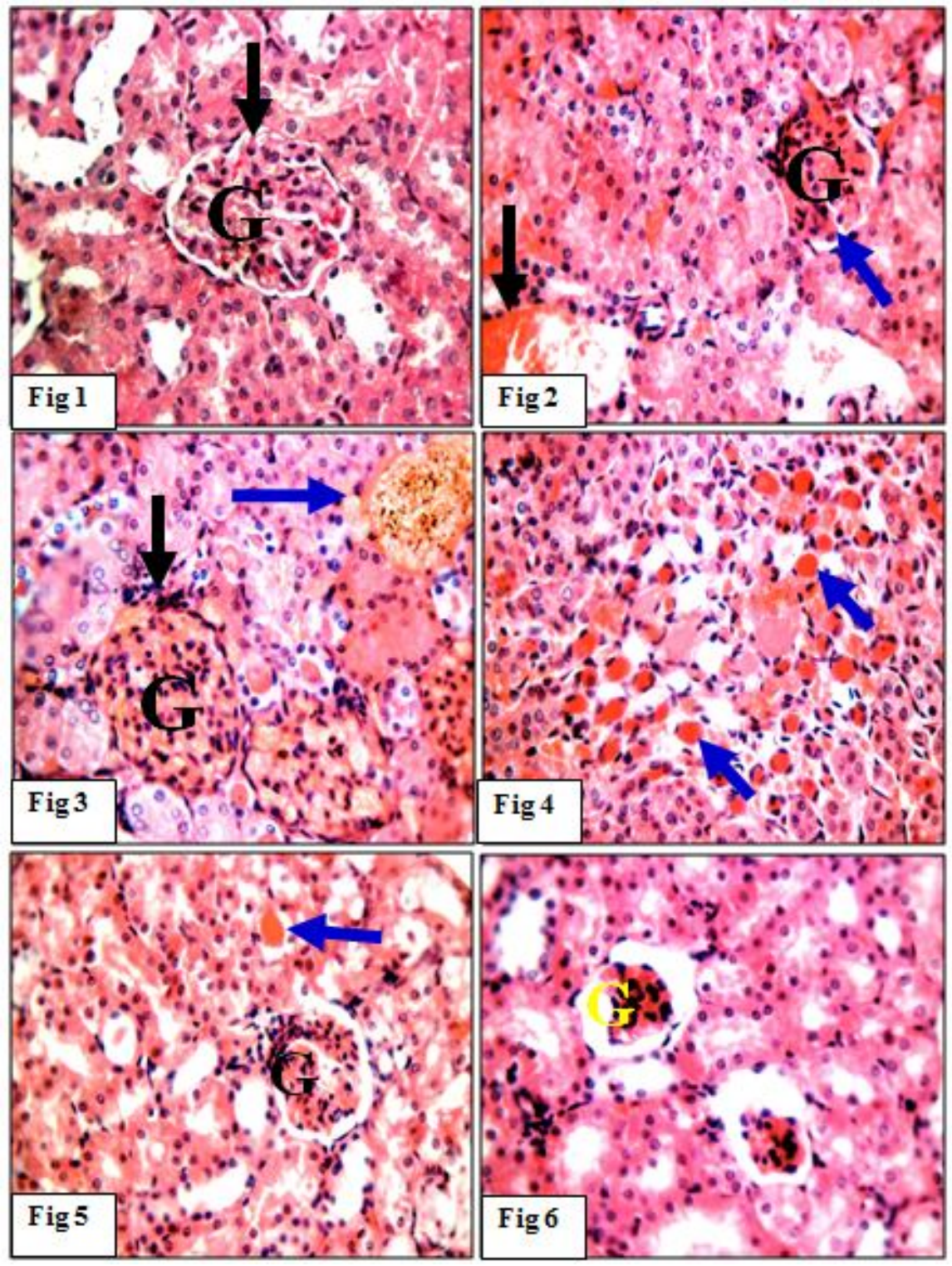

Fig (1): (Control). Fig (2) (Cisplatin low dose): Mild glomerular deformity and hypercellularity with markedly dilated congested blood vessels. Fig (3) (Cisplatin high dose): Marked glomerular deformity and hypercellularity with obliterated Bowman's spaces and markedly dilated congested blood vessels Fig (4): Numerous intra-tubular hyaline casts. Fig 5 (Cisplatin + Metformin low dose): Mild glomerular deformity with intra-tubular hyaline casts. Fig 6 (Cisplatin + Metformin high dose): Marked glomerular deformity and hypercellularity with mild tubular edema (H\&E X400)

\section{II- Histochemical results:}

Light microscopical examination of PAS and Mallory stained slides of kidneys showed the following:

- Group 1 (Control): PAS showed average glomerular and tubular BM with preserved brush borders, cell borders, and nuclear details (Fig 7 \& Table 4). Mallory's stain showed no fibrosis.

- Group II: (Cisplatin low dose): PAS showed mild thickening of glomerular BM. Renal tubules showed partially 


\section{EVALUATION OF THE POSSIBLE PROTECTIVE EFFECT OF METFO... 51}

preserved brush borders with partially preserved nuclear details and indistinct (poor) cell borders (Fig $8 \&$ Table 4). Mallory's stain showed thin irregular glomerular and tubular BM (Fig 13 \& Table 5)

- Group III: (Cisplatin high dose): PAS showed marked thickening of glomerular BM., Renal tubules showed partially preserved brush borders with loss of nuclear details (Fig 9 \& Tables 4). Mallory's stain showed thin irregular Bowman, s capsule and tubular BM (Fig 14 \& Table 5)

- Group IV: (Metformin high dose): PAS showed mild thickening of glomerular $\mathrm{BM}$, with preserved tubular BM and brush borders (Fig 10 \& Table 4). Mallory's stain: showed thin irregular Bowman, s capsule and tubular BM (Fig 15 \& Tables 5)

- Group V: (Cisplatin + Metformin low dose) PAS showed mild thickening of glomerular and tubular BM with partially preserved brush borders (Fig $11 \&$ Tables 4). Mallory's stain showed thick irregular Bowman, s capsule and tubular BM (Fig 16 \& Table 5).

- Group VI: (Cisplatin + Metformin high dose) PAS showed marked thickening of glomerular BM with preserved brush borders with loss of nuclear details of renal tubules (Fig $12 \&$ Table 4).

Table (4): PAS scoring

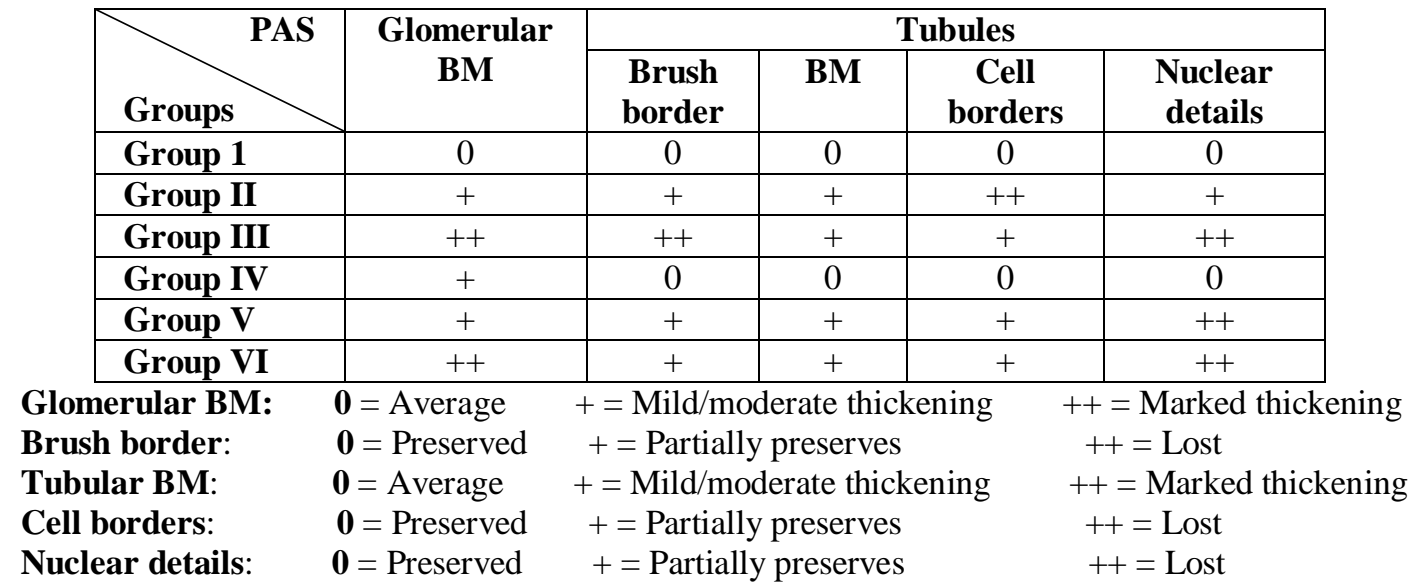

- Mallory's stain showed thick irregular glomerular and tubular BM, thick irregular Bowman, s capsule with scar formation (Fig 17) and medullary fibrosis (Fig $18 \&$ Tables 5).

Table (5): Mallory's stain results

\begin{tabular}{|c|c|c|c|c|c|c|}
\hline $\begin{array}{c}\text { Collagen } \\
\text { fibers } \\
\text { Stained deep } \\
\text { blue }\end{array}$ & Group 1 & Group 1I & Group III & Group 1V & Group V & Group V1 \\
\cline { 2 - 7 } & - & + & ++ & + & ++ & ++ \\
\hline
\end{tabular}

- = Negative: thin continuous collagen fibers.

$+=$ Thin irregular collagen fibers.

$++=$ Markedly thick irregular collagen fibers. 


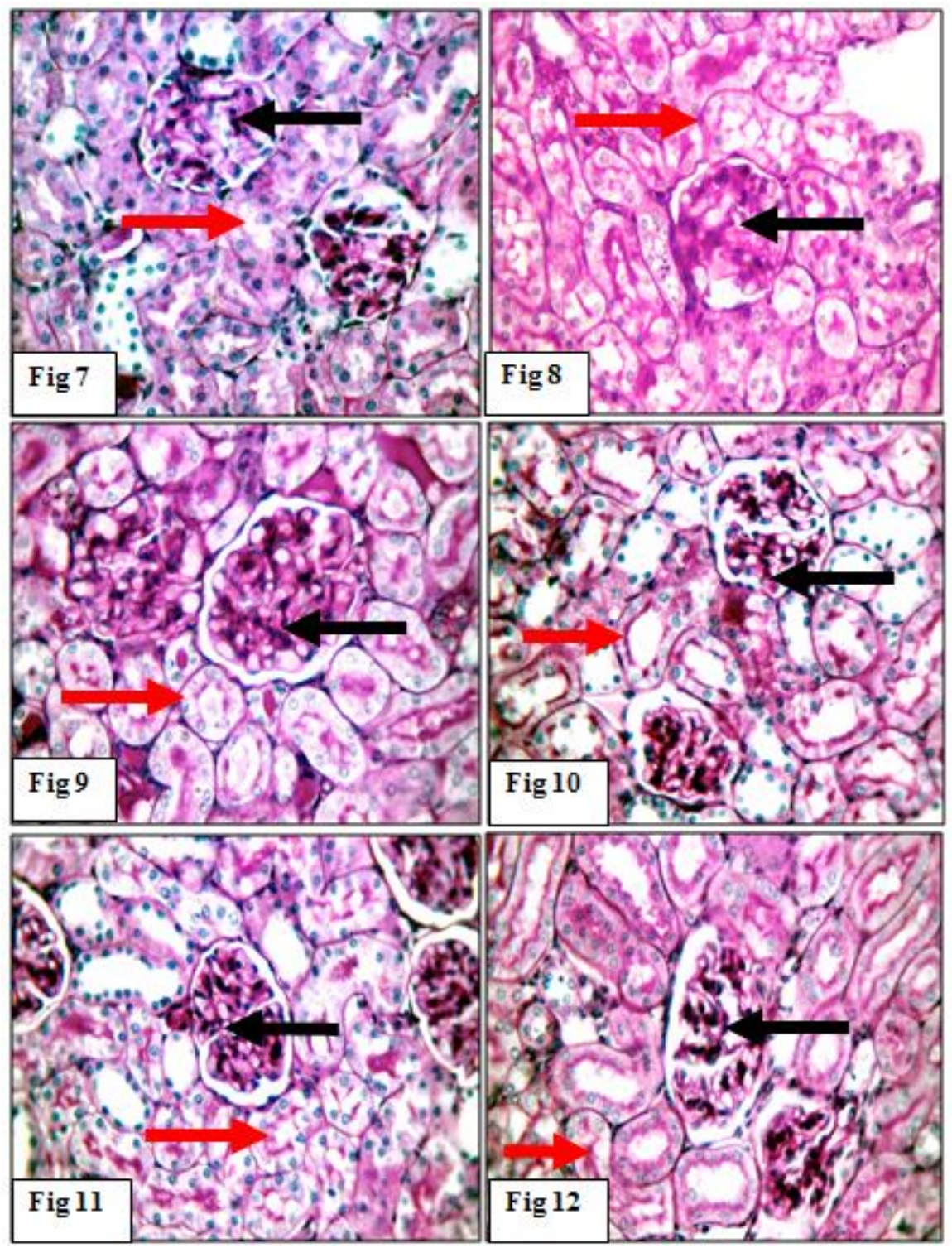

Fig 7 (Control): Average glomerular BM with preserved brush borders. Fig 8 (Cisplatin low dose): Mild thickening of glomerular BM with partially preserved brush borders. Fig 9 (Cisplatin high dose): Marked thickening of glomerular BM with partially preserved brush borders. Fig 10 (Metformin high dose): Mild thickening of glomerular BM with preserved brush borders. Fig 11 (Cisplatin + Metformin low dose): Mild thickening of glomerular BM with partially preserved brush borders. Fig 12 (Cisplatin + Metformin high dose): Marked thickening of glomerular BM with preserved brush borders (PAS stain X400) 
EVALUATION OF THE POSSIBLE PROTECTIVE EFFECT OF METFO... 53
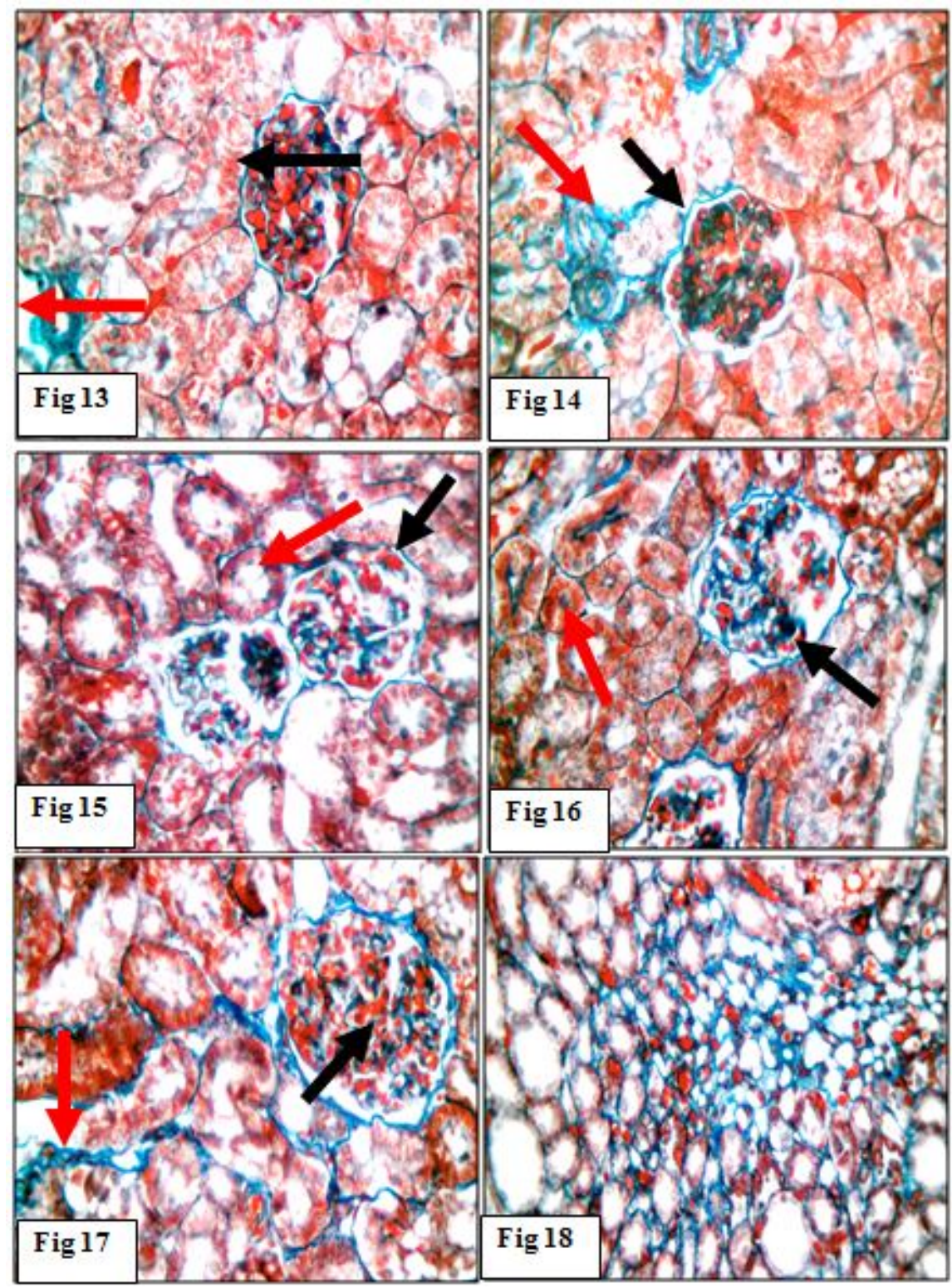

Fig 13 (Cisplatin low dose): Thin irregular glomerular \& tubular BM. Fig 14 (Cisplatin high dose): thick irregular Bowman's capsule and tubular BM. Fig 15 (Metformin high dose): Thin irregular Bowman, s capsule and tubular BM. Fig 16 (Cisplatin + Metformin low dose): Thick irregular Bowman, s capsule and tubular BM. Fig 17 (Cisplatin + Metformin high dose): Thick irregular glomerular BM, Bowman, s capsule and tubular BM. Fig 18 (Cisplatin + Metformin high dose): Medullary fibrosis (Mallory's stain X400) 


\section{DISCUSSION}

Cisplatin is well known for its nephrotoxic effects producing many histopathological changes like vascular congestion, focal mononuclear cell inflammatory, cellular infiltrate, acute tubular injury with reactive atypia and apoptotic cells (Alhoshani et al. (2017) marked necrosis of proximal tubules and degeneration of the tubular epithelial cells which is related to an increase in lipid peroxidation, oxygen-free radicals, and inflammation in kidney (Kundan et al. (2013). Pezeshki et al., 2017, suggested that the cisplatin -induced nephrotoxicity started to develop almost 3 days after administration of the drug in rats.

Metformin had been suggested to have therapeutic or reno-protective effects against nephrotoxic agents (Nasri, 2013 and Rafieian-Kopaei \& Nasri, 2013). Li et al. (2016) demonstrated that metformin may protect against cisplatin-induced tubular cell apoptosis. Sahu et al., (2013) showed in their study marked ameliorative effects of metformin on renal functions and attributed this improvement to antioxidant and cytoprotective effects of metformin.

Our study showed obvious decrease in average total body weight of rats given cisplatin injection. These results agree with results of the study of Akunna et al. (2018) who showed a significant decrease in final body weight of cisplatin treated rats. Our study showed that this average loss of body weight was noted to be less on giving metformin with cisplatin.
Sahu et al. (2013) reported that a single injection of cisplatin $(7.5 \mathrm{mg} / \mathrm{kg}$, i.p.) caused a significant increase in blood urea nitrogen and serum creatinine. These results were in accordance to our findings which showed marked increase in renal functions on giving cisplatin injection which were more elevated on increasing cisplatin injected dose from $3.5 \mathrm{mg} / \mathrm{kg}$ to $7.5 \mathrm{mg} / \mathrm{kg}$. When metformin was given, blood urea nitrogen and serum creatinine levels were decreased. Amini et al. (2012) showed that post-treatment with metformin or co-treatment could prevent the elevation of serum BUN and that metformin may prevent or ameliorate gentamycin induced acute renal failure.

Our histopathological study showed marked histological changes as seen by H\& $\mathrm{E}$ on giving cisplatin injection (3.5 $\mathrm{mg} / \mathrm{kg}$ ) and when the injected dose of cisplatin was increased from $3.5 \mathrm{mg}$ to 7.5 $\mathrm{mg}$; more cortical necrosis occurred, viable glomeruli showed marked deformity and hypercellularity with obliterated Bowman's spaces, tubular epithelia showed numerous necrotic/ apoptotic tubular cells with numerous intra-tubular hyaline casts and Interstitial tissues showed markedly dilated congested blood vessels which agrees with the study of Sahu et al. (2013) who reported that a single injection of cisplatin $(7.5 \mathrm{mg} / \mathrm{kg}$, i.p.) caused a significant renal damage.

On giving single injection of $7.5 \mathrm{mg}$ cisplatin + metformin $100 \mathrm{mg} / \mathrm{kg} /$ day, mild glomerular deformity and cellularity and patent Bowman's spaces were seen. Proximal tubular epithelia were less 


\section{EVALUATION OF THE POSSIBLE PROTECTIVE EFFECT OF METFO... 55}

oedematous with scattered necrotic/ apoptotic epithelial cells, while distal tubular epithelium was edematous with few intra-tubular hyaline casts. Obvious less necrosis/ apoptosis was seen with narrow to patent Bowman's spaces and mildly oedematous tubular epithelial cells and less interstitial congestion and few intra-tubular hyaline casts were seen in rats which were given $7.5 \mathrm{mg}$ cisplatin+ metformin $350 \mathrm{mg} / \mathrm{kg} /$ day for 10 days. It was also notable that the effects of $100 \mathrm{mg} / \mathrm{kg}$ metformin $+7.5 \mathrm{mg} / \mathrm{kg}$ cisplatin was much better than giving 350 $\mathrm{mg} / \mathrm{kg}$ metformin with same high dose of cisplatin $(7.5 \mathrm{mg} / \mathrm{kg})$ for same 10 days period.

Our histochemical study using PAS and Mallory stains showed that $3.5 \mathrm{mg} / \mathrm{kg}$ injected dose of cisplatin led to mild thickening of glomerular BM, partially preserved cell and brush borders of tubules and that on increasing the injected dose of cisplatin to $7.5 \mathrm{mg} / \mathrm{kg}$ marked thickening of glomerular BM with more loss of renal tubular brush borders were noted. Cisplatin + metformin groups showed more preservation of brush borders especially on increasing the dose of metformin to $350 \mathrm{mg} /$ day where better preservation of brush borers of tubules was noted. Our findings were in accordance with other studies that proved that metformin preserved brush borders, decreased cell death and the damaging effects of cisplatin. Metformin proved to minimize the damaging effects of cisplatin. These findings were similar to findings of Fatemeh et al. (2012) who concluded from their study that metformin is a nephron-protective drug that could attenuate the tubular damage caused by gentamycin or other nephrotoxic agents.
Reduction of apoptosis, induced by oxidative stress, in endothelial cells and prevention of vascular dysfunction was found with metformin treatment (Nasri, 2013). Also, Taheri et al., 2012, reported found that there was an ameliorative property of metformin against unilateral ischemia-reperfusion induced injury in rats.

\section{CONCLUSION}

Metformin produced significant protection against cisplatin-induced nephrotoxicity especially in low dose.

\section{REFERENCES}

1. Abdel-Daim M. M., El-Sayed Y. S., Abd Eldaim M. and Ibrahim A. (2017): Nephro-protective efficacy of ceftriaxone against cisplatin-induced subchronic renal fibrosis in rats., Arch Pharmacol., 390:301309.

2. Akunna G.G., Obikili E.N., Anyawu G.E. and Esom E.A. (2018): Histochemical and morphometric evidences of the curative role of aqueous zest extract of Citrus sinensis on anti-neoplastic drug-induced testicular degeneration in animal models., Eur. J. Anat. 22 (6): 497-507.

3. Alhaider A.A., Korashy H.M., SayedAhmed M.M., Mobark M., Kfoury H. and Mansour M.A. (2011): Metformin attenuates streptozotocin-induced diabetic nephropathy in rats through modulation of oxidative stress genes expression., Chem Biol Interact., 192(3):233-42.

4. Alhoshani A. R., Hafez M. M., Husain S., Al-sheikh A. M., Alotaibi M. R., Al Rejaie S. S., Alshammari M. A., Almutairi M. M. and Al-Shabanah O. A. (2017): Protective effect of rutin supplementation against cisplatin-induced Nephrotoxicity in rats., BMC Nephrology, 18:194- 204.

5. Amini F.G., Rafieian-Kopaei M., Nematbakhsh M., Baradaran A. and Nasri H. (2012): Ameliorative effects of metformin on renal histologic and 
biochemical alterations of gentamicininduced renal toxicity in Wistar rats., J Res Med Sci., 17:621-5.

6. Chirino Y. and Pedraza-Chaverri J. (2009): Role of oxidative and nitrosative stress in cisplatin-induced nephrotoxicity., xp Toxicol Pathol., 61:223 $\square 242$.

7. Dasari S. and Tchounwou P.B. (2014): Cisplatin in cancer therapy: molecular mechanisms of action., Eur J Pharmacol., 740:364-78

8. Dehkordi A. H., Abbaszadeh A., Mir S. and Hasanvand A (2019): Metformin and its anti-inflammatory and anti-oxidative effects; new concepts, J Renal Inj Prev., 8(1):54-61.

9. Fatemeh H., Mehran H., Shokouh S., Abedi-Gheshlaghi Z. and Seyed S. B. M. (2016): Prevention of cisplatin nephrotoxicity, J Nephropharmacol., 5 (1): 57-60.

10. Florea A.M. and Büsselberg D. (2011): Cisplatin as an anti-tumor drug: cellular mechanisms of activity, drug resistance and induced side effects. Cancers, 3:1351-1371.

11. Gabbiani C., Magherini F., Modesti A. and Messori L. (2010): Proteomic and metallomic strategies for understanding the mode of action of anticancer metallodrugs. Anticancer Agents. Med Chem., 10: 324-37

12. Kim J., Shon E., Kim C.S. and Kim J.S. (2012): Renal Podocyte Injury in a Rat Model of Type 2 Diabetes Is Prevented by Metformin. Exp. Diabetes Res., 2012:1-9.

13. Kundan G. I., Thakurdesai P.A. and Vyawahare N. S. (2013): Protective effect of Hygrophila spinosa against cisplatin induced nephrotoxicity in rats. Indian $\mathbf{J}$ Pharmacol., 45(3): 232-236.

14. Li J., Gui Y., Ren J., Liu X., Feng Y., Zeng Z., He W., Yang J. and Dai C. (2016): Metformin Protects Against Cisplatin-Induced Tubular Cell Apoptosis and Acute Kidney Injury via AMPK $\alpha$ regulated Autophagy Induction., Sci Rep. 6: $1-15$.
15. Nasri H. (2013): Reno-protective effects of metformin, Daru J. of Pharmaceutical Sciences, 21(1): 1-3.

16. Peres LA and da Cunha A. D J. (2013): Acute Nephrotoxicity of Cisplatin: Molecular mechanisms, J. Bras. Nefrol; 35(4):332-340.

17. Pezeshki Z., Khosravi1 A., Nekuei1 M., Khoshnood S., Zandi E., Eslamian M., Talebi1 A., $r$ Emami S. N. and Nematbakhsh M. (2017): Time course of cisplatin-induced nephrotoxicity and hepatotoxicity. Nephropathol. 6(3):163-167

18. Rafieian-Kopaei M., Baradaran A., Merrikhi A., Nematbakhsh M., Madihi Y. and Nasri H. (2013): Efficacy of Coadministration of Garlic Extract and Metformin for Prevention of GentamicinRenal Toxicity in Wistar Rats: A Biochemical Study., Int J Prev Med, 4(3): 258-264.

19. Rafieian-Kopaei M and Nasri H. ( 2013): Ginger and diabetic nephropathy., J Ren Inj Prev., 2(1): 9-10.

20. Sahu B.D., Kuncha M., Putcha U.K. and Sistla R. (2013): Effect of metformin against cisplatin induced acute renal injury in rats: A biochemical and histo-architectural evaluation, Experimental and Toxicologic Pathology, 65 (6): 933-940.

21. Taheri N., Azarmi Y., Neshat M., Garjani A. and Doustar Y. (2012): Study the effects of metformin on renal function and structure after unilateral ischemia-reperfusion in rat. Res Pharm Sci., 18(7): 62-8.

22. Zsuzsanna K. Z., Ellezian L., Brown D., Horv?th B., Mukhopadhyay P, Kalyanaraman B., Parikh S. M., Karumanch S. A., Stillman I. E. and Pacher P. (2012): Cisplatin Nephrotoxicity Involves Mitochondrial Injury with Impaired Tubular Mitochondrial Enzyme Activity. J Histochem Cytochem., 60(7): 521-529. 
EVALUATION OF THE POSSIBLE PROTECTIVE EFFECT OF METFO... 57

تقييم التأثثرات الواقية المحتملة للميتفورمين على التسمح الكلوي المحدث من السيسبلاتين على الجرذان البيضاء البهاء

محمد عساسة*، سبد عبد الرحيم***، عبد اللطيف سيد***، أشرف إبراهيم حسن*

أقسام الطب الثرعي* والباثولوجي ** والفارماكولوجي****، كلية طب، جامعة الأزهر

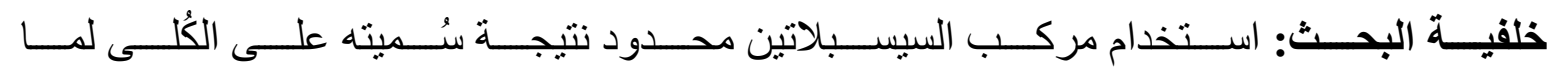
يُحدثه من زيادة إضطر اب الأكسدة، مما يؤدي في النهاية لخلل وظائف الكُلى.

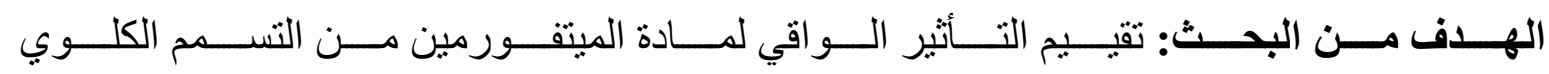
المُحدث من مادة السيسبلاتين لجرذان التجارب البيضاء البالغة.

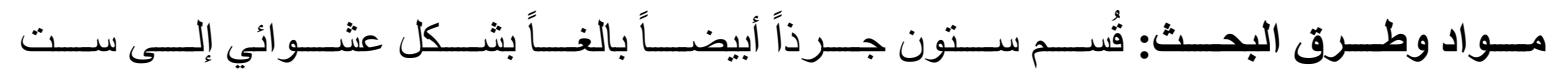

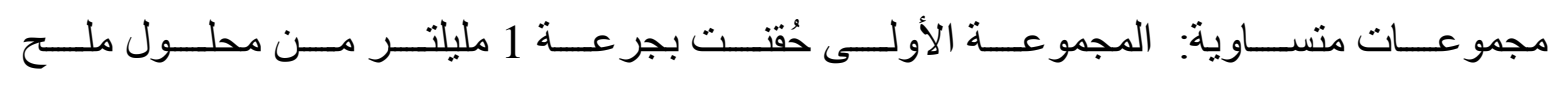

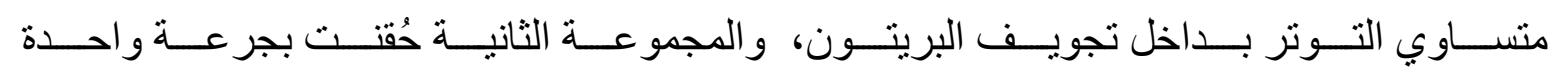

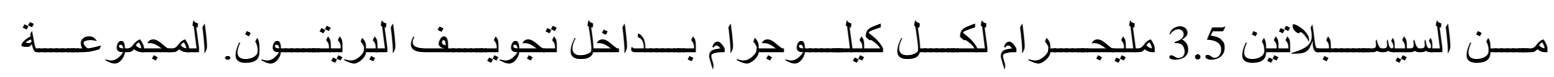

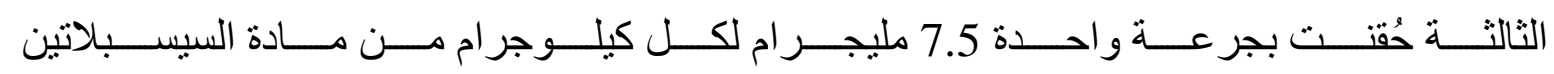

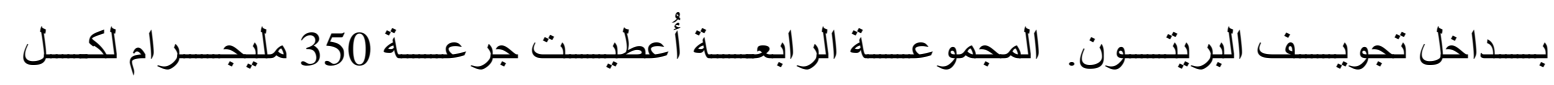

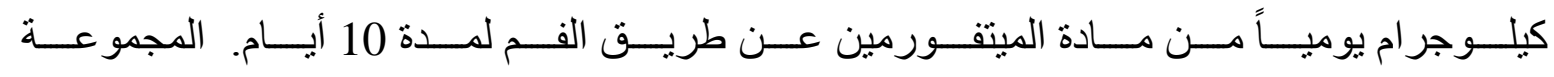

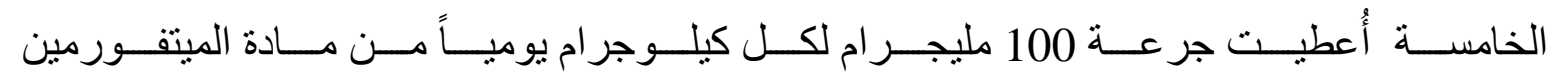

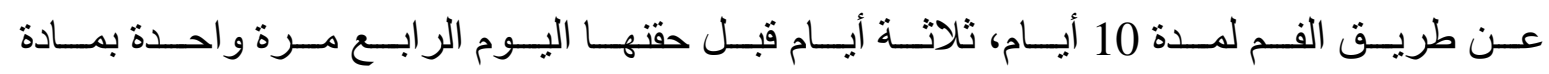

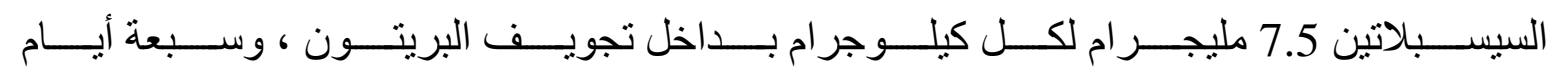

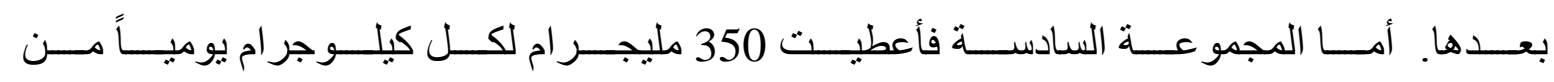

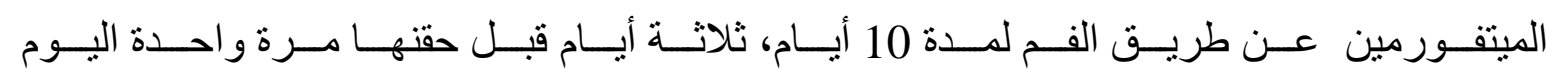

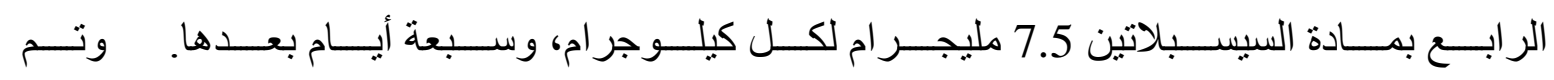

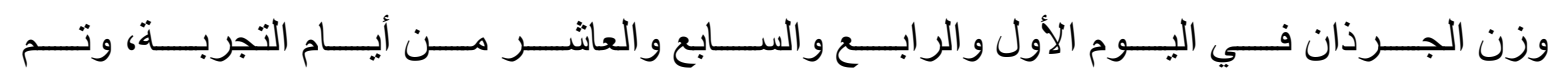

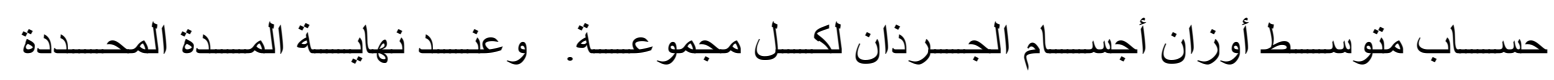

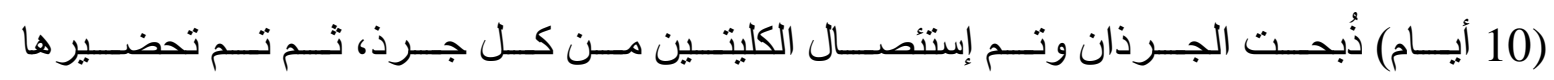

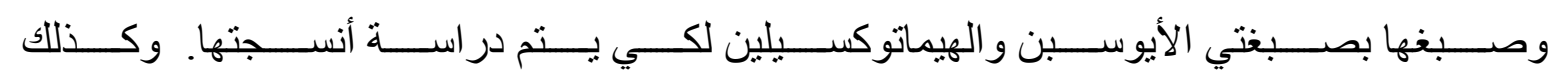
صبغها بصبغتي المالوري وشيف الحامضية الدورية لفحص أنسجتها كيميائياً. 


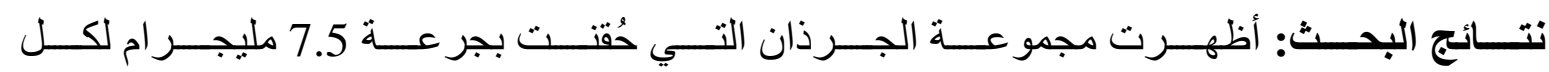

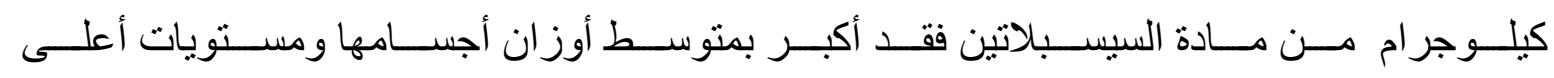

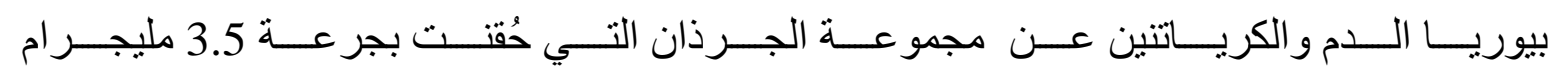

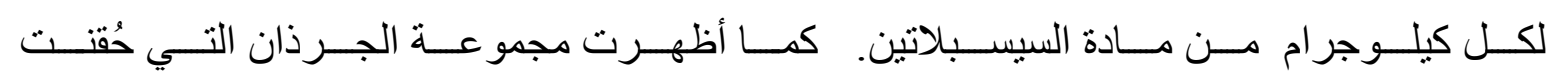

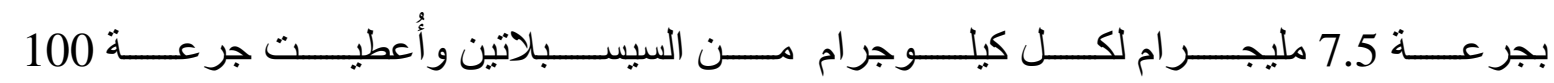

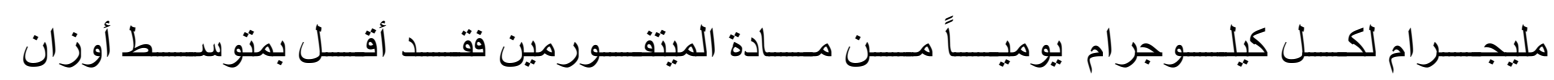

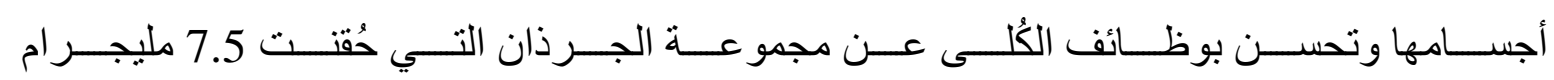

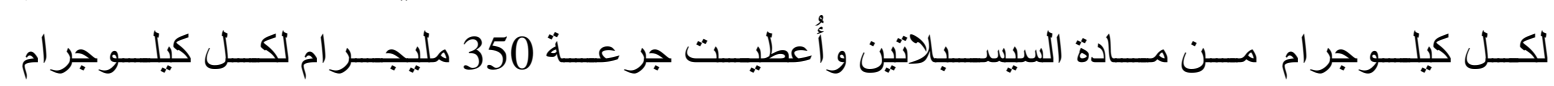

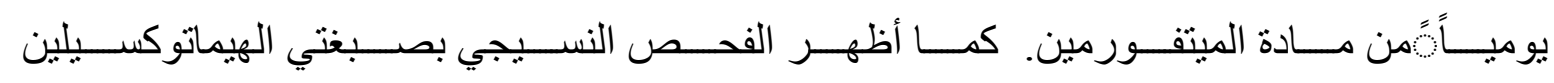

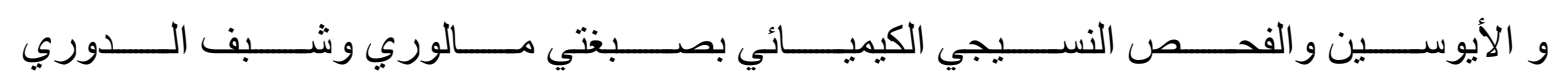

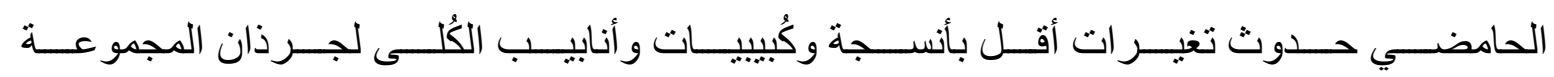

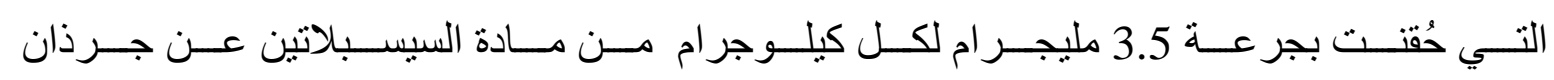

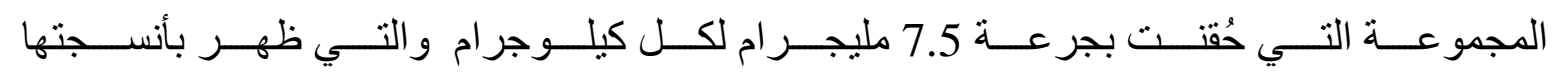

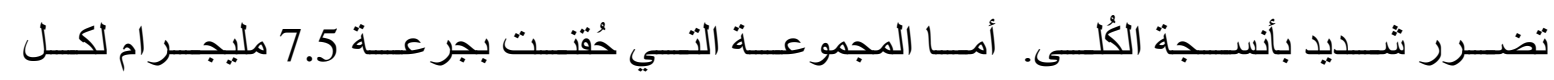

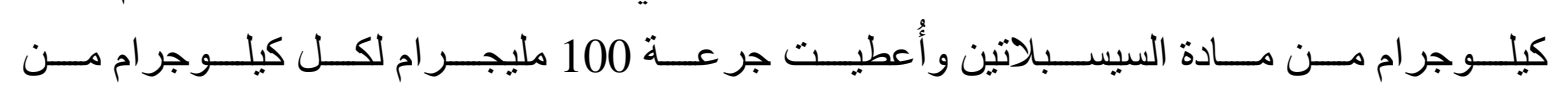

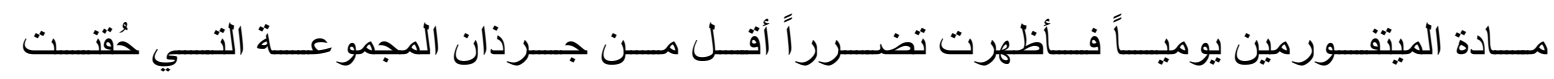

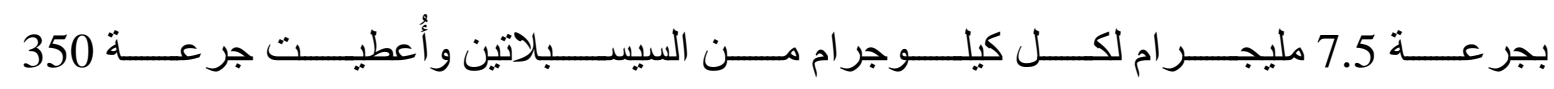
مليجر ام لكل كيلوجر ام يومياً من مادة الميتفورمين.

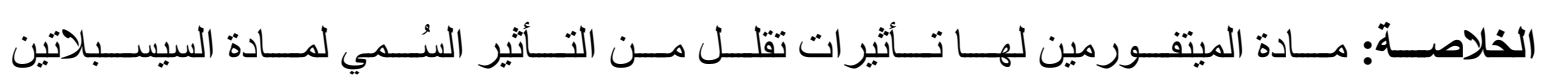
على كُلى الجرذان الذكور البيضاء البالغة. 